\title{
Nauplius
}

The Journal OF The

Brazilian Crustacean Society

This article is part of the tribute offered

by the Brazilian Crustacean Society

in memoriam of Michael Türkay for his

e-ISSN 2358-2936

www.scielo.br/nau www.crustacea.org.br

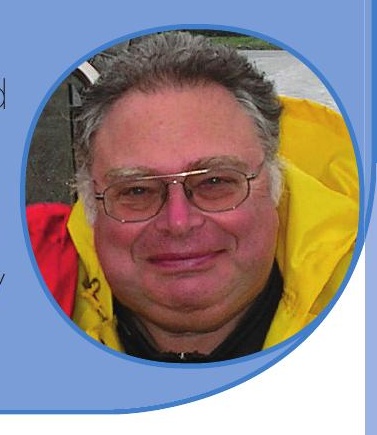

Original Article

\section{Population dynamics of the mud crab Panopeus austrobesus Williams, 1983 (Brachyura: Panopeidae) associated with a mussel farm at the southeastern Brazilian coast}

Flavio de Vasconcelos Camargo ${ }^{1}$, Douglas Fernandes

Rodrigues Alves², Daniel José Marcondes Lima

and Valter José Cobo ${ }^{4}$

1 Fundação de Ensino e Pesquisa de Itajubá (FEPI), Núcleo de Estudos de Macroinvertebrados e Crustáceos de Água Doce. Av. Dr. Antônio Braga Filho, 687. 37501-002 Itajubá, Minas Gerais, Brazil.

FVC E-mail: flaviobiol@yahoo.com.br

2 Universidade Federal de Sergipe. Av. Marechal Rondon, s/n Jardim Rosa Elze. 49100-000 São Cristóvão, Sergipe, Brazil.

DFRA E-mail: douglas_biologo@yahoo.com.br

3 Universidade Estadual Paulista (UNESP), Departamento de Zoologia, Instituto de Biociências de Botucatu. Distrito de Rubião Júnior, s/n. 18618-970 Botucatu, São Paulo, Brazil.

DJML E-mail: danieljmlima@gmail.com

4 Laboratório de Biologia Marinha (LabBMar), Instituto Básico de Biociências, Universidade de Taubaté (UNITAU). Av. Tiradentes, 500. 12030-180 Taubaté, São Paulo, Brazil.

VJC E-mail: vjcobo@gmail.com

ZOOBANK http://zoobank.org/urn:lsid:zoobank.org:pub:B2D2CD49-FE6A-4026B753-8C74B6BF3F00

CORRESPONDING AUTHOR

Valter José Cobo

vjcobo@gmail.com

SUBMITTED 31 October 2016

ACCEPTED 22 March 2017

PUBLISHED 22 June 2017

Guest Editor

Célio Magalhães

DOI 10.1590/2358-2936e2017017

\section{Abstract}

Mussel farms are one of the most important modalities of aquaculture and constitute almost $80 \%$ of the total bivalve production in Brazil, representing about $5 \%$ of the national production. Brachyuran crabs are common inhabitants of these environments and represent an important link in coastal marine food chains. The aim of this investigation is to describe the population structure 
of Panopeus austrobesus Williams, 1983 in a Perna perna (Linnaeus, 1758) farm located at the southeastern Brazilian coast. The samplings were carried out in the northeastern coast of São Paulo State. From May 2002 to April 2003, one mussel net was recovered monthly, and all individuals of $P$. austrobesus were collected. Population size-frequency analysis indicated a unimodal and non-normal distribution. Males were significantly larger than females, and the overall sex ratio significantly skewed from 1:1, female-biased. Recruitment occurred during the entire period, and ovigerous females were found in 11 months. The onset of sexual maturity was estimated around $5 \mathrm{~mm}$ cephalothorax width. Mussel farms represent an anthropogenic intervention in the sea landscape, causing environmental changes. However, these structures must allow species introduction, increasing their ecological and geographical distribution, and provide available space and food to establish new populations. This is particularly important for species with small populations, such as $P$. austrobesus. The results of this study attest the environmental counterpart role of the mussel farms. Once they can support populations, they may also help to reintroduce them into the area and could therefore be used in a consortium generating economic profits and acting as bioremediation tool, assuring the maintenance of the genetic patrimony.

\section{KEY WORDS}

Brown mussel, conservation, mariculture, Perna perna, Ubatuba.

\section{INTRODUCTION}

Mussel farms are one of the most important modalities of aquaculture. They represent an efficient way to obtain seafood and have become a strategic economic activity in some places around the world (FAO, 2012). In Brazil, bivalve mariculture represents about $5 \%$ of the national production. The most important aquaculture in Brazil is the cultivation of the mussel Perna perna (Linnaeus, 1758), which constitutes almost $80 \%$ of the total bivalve production. Yields are second only to those of farmed fishes (e.g., Nile tilapia, carp, and "tambaqui") and the Pacific white shrimp Penaeus vannamei Boone, 1931 (Boscardin, 2007).

The production in these farms may be stimulated by continental budgets (Kemp and Boynton, 1984), nutrient cycling at the sediment-water interface (Herbert, 1999; Gibbs et al., 2005) and, over the coastal upwelling systems, by nutrient enrichment from offshore waters (Wooster et al., 1976; Fraga, 1981). However, these farms also represent the introduction of hard structures on the water column (mussel rafts). Given the changing landscape, mussel rafts may affect the original community through three main mechanisms: the creation of a stable substratum; the provision of shelter against predators, physical, and physiological stress; and the control of particles and solutes transported to the benthonic environment (Gutierrez et al., 2003).
Therefore, mussel farms may impose a new habitat where they are installed, promoting abiotic and biotic changes in their environments; these changes have the potential to alter species richness and the population dynamics of those species that eventually will explore this new space in the pelagic zone (see Thiel and Ullrich, 2002; Cinar et al., 2008; Antoniadou et al., 2013).

Brachyuran crabs of the Panopeidae family are common inhabitants of shallow waters, exploring both hard and soft bottoms, even in the intertidal zone (Melo, 1996). Panopeus austrobesus Williams, 1983 is a small crab with a large ecological range, found in bays and estuaries, digging galleries in the mud and walking on rocks and coral heads in reef zones. Its geographical distribution is restricted to the Western Atlantic Ocean, from Brazil (Rio de Janeiro to Rio Grande do Sul) to Uruguay (Melo, 1996; Peluffo, 2004).

In spite of the importance of P. austrobesus as a primary consumer, especially in estuarine zones, information concerning the main features of its biology remains lacking. Except for studies related to taxonomy, composition, and geographical distribution (e.g., Melo, 1996; Vieira and Calazans, 2010; Marochi and Masunari, 2011; Alves et al., 2012a; 2012b; Macedo et al., 2012), there is only a limited number of studies on the biology and ecology of P. austrobesus (see Montú et al., 1988; Negreiros-Fransozo and Fransozo, 2003). The aim of this investigation is to describe the population structure and dynamics of $P$. austrobesus associated with 
P. perna mussel farms on the southeastern Brazilian coast and to compare its main characteristics to those of populations in their natural environments.

\section{Material and Methods}

\section{Study area and sampling methods}

The northeastern coast of the São Paulo State is included on the Brazilian southeastern continental shelf, within more than $270,000 \mathrm{~km}^{2}$, which represents a typical modern shelf hydrodynamically constrained (Mahiques et al., 2004) and the only zone of the Brazilian coast with transitional environments from the subtropical to the temperate zones (Rocha et al., 1975). The continental hydrodynamic shelf patterns along the southeastern coast of Brazil are driven by seasonal events, mainly those in regards to water masses and winter cold fronts (Castro-Filho et al., 1987). Three main water masses converging at this zone define the water temperature $(\mathrm{T})$ and salinity (S): The Coastal Water $(\mathrm{CW})\left(\mathrm{T}>20^{\circ} \mathrm{C}, \mathrm{S}<36\right)$, South Atlantic Central Waters (SACW) $(8.7<\mathrm{T}<$ $\left.20^{\circ} \mathrm{C}, 34.66<\mathrm{S}<36.2\right)$, and Tropical Waters (TW) $(\mathrm{T}$ $>20^{\circ} \mathrm{C}, \mathrm{S}>36.2$ ) (Castro-Filho and Miranda, 1998).

Sampling was carried out on Itaguá Beach, municipality of Ubatuba, northeastern coast of São Paulo State $\left(23^{\circ} 27^{\prime} 07^{\prime \prime} S 45^{\circ} 02^{\prime} 49^{\prime \prime} \mathrm{W}\right)$ (Fig. 1). From May 2002 to April 2003, one mussel net was recovered from the sea farm each month and all individuals of $P$. austrobesus were collected. Environmental parameters, such as bottom water temperature and salinity, were evaluated daily, obtaining monthly means to recognize the prevalent water mass in the studied site during the sample period. The obtained material was transferred to the Laboratory of Marine Biology, University of Taubaté, where the crabs were separated and stored in labeled jars filled with $70 \%$ alcohol. The individuals were sexed and grouped into juveniles or adults based on abdomen morphology and ovigerous condition (egg masses attached to the pleopods).

Additionally, the individuals were grouped into five demographic categories: juvenile male (JM), adult male (AM), juvenile female (JF), non-ovigerous adult female (NOAF), and ovigerous female (OF). Carapace width $(\mathrm{CW})$ was measured under a stereomicroscope and the crabs were grouped into different size classes. Identification was performed according to Melo (1996) and classification followed $\mathrm{Ng}$ et al. (2008).

\section{Data analysis}

Normality of the distribution of size frequency was assessed through Shapiro-Wilk test; size comparisons between sexes were performed by Mann-Whitney test (both with $\alpha=0.05$ ). The sex ratio was estimated as the quotient between the number of males and the total number of individuals obtained. Thus, sex ratio values higher or lower than 0.5 indicate population skews toward males or females, respectively. Month and size class distributions were tested for deviations from a 1:1 sex ratio; monthly frequencies of ovigerous and non-ovigerous were compared by the binomial test (Wilson and Hardy, 2002).

Monthly absolute abundance of crabs was correlated with salinity and bottom water temperature, using the Spearman test $(\alpha=0.05)$. Modal curves were detected and fitted according to the monthly frequency distribution by the Automatic Peak Detection and Fitting, Method I - Residuals (Pimenta et al., 2005; Keunecke et al., 2007); recruitment was detected as the presence of the modes in the firsts size classes, suggesting the entrance of juveniles into the population.

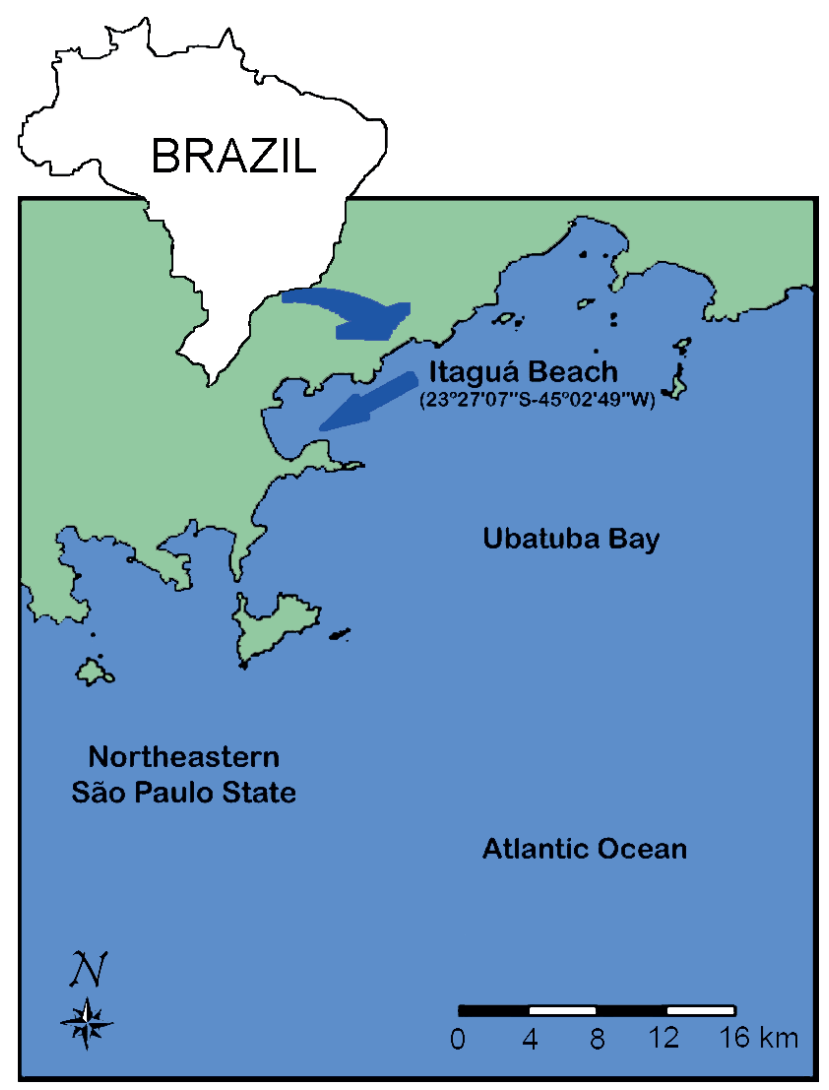

Figure 1 . Northeastern coast of São Paulo, Ubatuba Bay; arrow points out Itaguá Beach, Ubatuba. 
Size at sexual maturity was estimated as the CW class within at least 50\% morphologically mature individuals, using the interpolation of the logistic equation, adjusted by the least square method, over the data of the relationship between mature individual proportion (PA) and CW class (CWC) (see details in Aguilar et al., 1995; Vazzoler, 1996).

\section{Results}

A total of 962 specimens of $P$. austrobesus were recorded, 451 males and 511 females, and distributed into five demographic categories: 230 JM, 221 AM, 127 JF, 157 NOAF, and 227 OF (Fig. 2). The crabs were distributed into ten size classes with a 1-mm CW interval. The population size frequency analysis indicated a unimodal and non-normal distribution for P. austrobesus (Shapiro-Wilk test, $\mathrm{W}=0.988, \mathrm{p}<0.001$; see Fig. 3 ). The mean size recorded for the sampled population was $5.59 \pm 1.9 \mathrm{~mm} \mathrm{CW}$, ranging from 1.5-11.1 mm. Males $(\mathrm{M}=5.74 \pm 1.54$; range $=1.5-11.1 \mathrm{~mm} \mathrm{CW} ; \mathrm{n}=451)$ were significantly larger than females $(M=5.40 \pm 2.20$; range $=1.8-9.1 \mathrm{~mm} \mathrm{CW} ; \mathrm{n}=511$; Mann-Whitney $\mathrm{U}$ test, $\mathrm{U}=98422.00, \mathrm{p}<0.001)$.

The overall sex ratio recorded during the study period was $1: 1.13\left(\chi^{2}=3.74 ; \mathrm{p}=0.053\right)$, with a significant departure from 1:1, female-biased. Skewed sex ratios were verified for males in the initial and final size classes and for females in the intermediate size

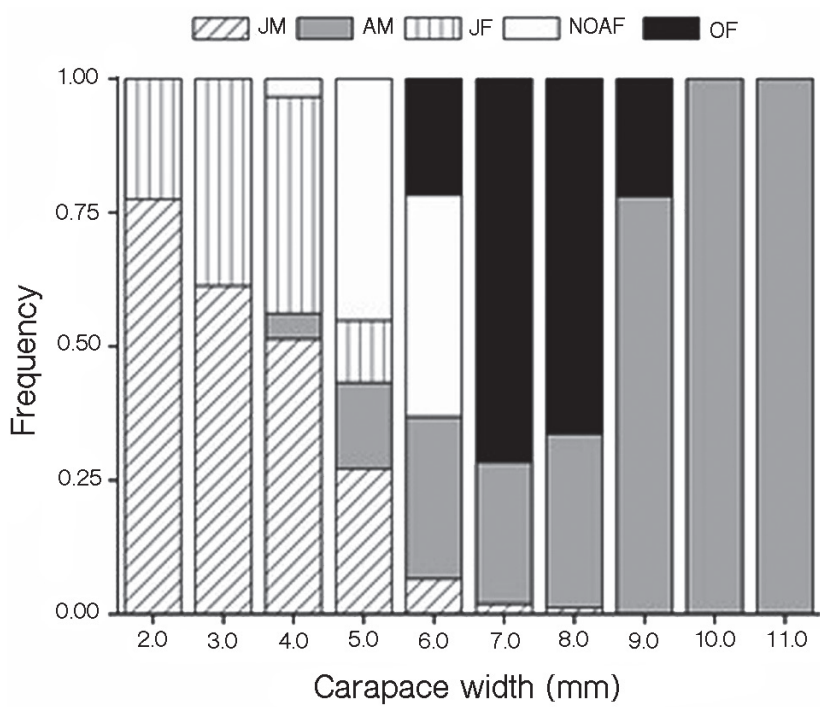

Figure 2. Frequency of Panopeus austrobesus by size class in the mussel farm at Itaguá Beach, Ubatuba, State of São Paulo, Brazil (JM, juvenile male; AM, adult male; JF, juvenile female; NOAF, non-ovigerous adult female; OF, ovigerous females). classes (Fig. 4). During the study period, sex-ratio skews were detected in December 2002 (1:2.56; $\mathrm{p}<$ $0.001)$ and January 2003 (1:1.63; p < 0.001), and all of them were biased toward females (Fig. 5).

Juveniles were distributed in the size classes from 1.5-2.5 to 7.5-8.5 $\mathrm{mm} \mathrm{CW}$. Adults were recorded mainly in the $3.5-4.5 \mathrm{~mm} \mathrm{CW}$ size class. Nonovigerous females were absent only from the largest size class, where only adult males were recorded, and the ovigerous females were concentrated in the size classes from 5.5-6.5 to 9.5-10.5 mm CW.

Based on the size frequency distribution data, juveniles were recorded in almost all sampled months,

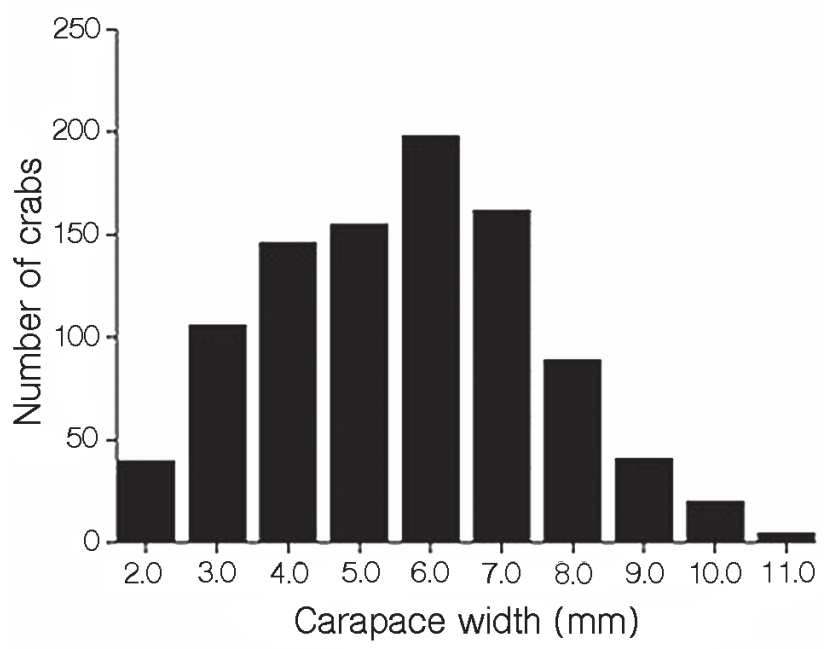

Figure 3. Size frequency distribution of body size (CW) of Panopeus austrobesus in the mussel farm at Itaguá Beach, Ubatuba, State of São Paulo, Brazil.

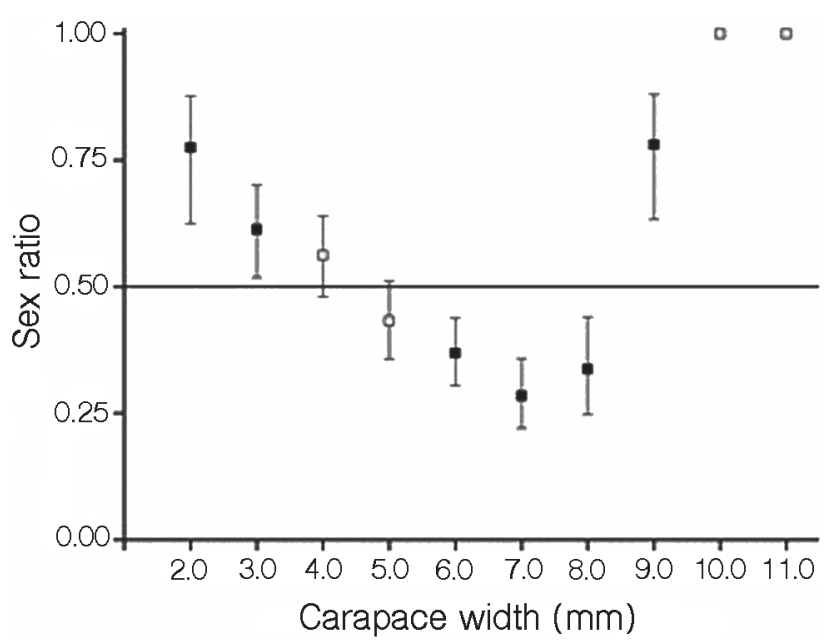

Figure 4. Sex ratio (estimate \pm SD) by size class of Panopeus austrobesus in the mussel farm at Itaguá Beach, Ubatuba, State of São Paulo, Brazil. Black squares indicate a deviation from a 1:1 sex ratio. 
and the recruitment of $P$. austrobesus was recorded during the entire sampling period, considering the modal curve evaluation (Fig. 6). Ovigerous females occurred in 11 months, with the main peak occurring in January and February 2003, when significant differences in the abundance of non-ovigerous females were observed (binomial test, $\mathrm{p}<0.05$ ). The smallest $\mathrm{AM}$ and the largest JM measured 3.8 and $6.8 \mathrm{~mm} \mathrm{CW}$, respectively, while the smallest $\mathrm{AF}$ and the largest JF measured 4.0 and $5.1 \mathrm{~mm} \mathrm{CW}$, respectively. Based on the logistic function, the onset of sexual maturity was estimated to occur at around $5 \mathrm{~mm} \mathrm{CW}$ for both sexes (Fig. 7).

During the sampling period, the temperature of the water at the bottom ranged from 18.6 to $28.5^{\circ} \mathrm{C}(24.3$

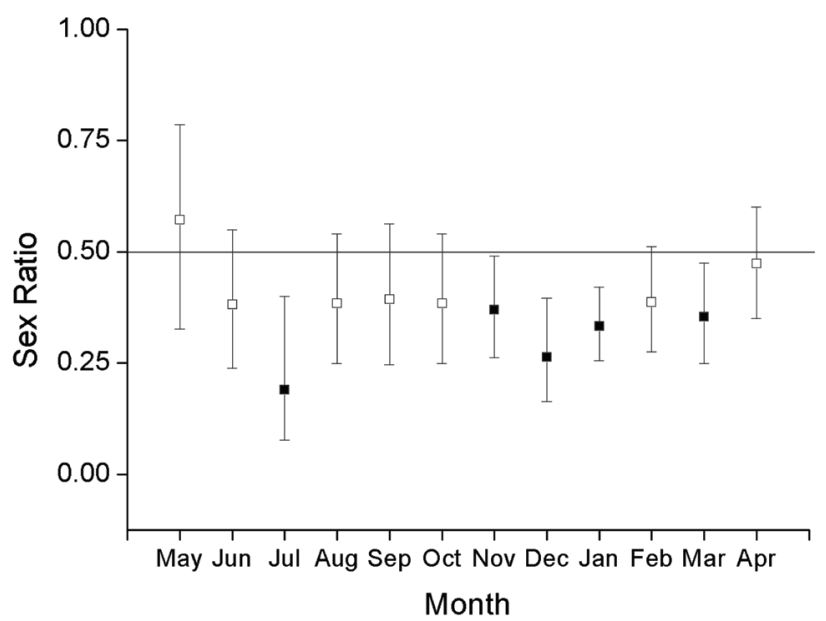

Figure 5. Sex ratio (estimate \pm SD) by month of Panopeus austrobesus in the mussel farm at Itaguá Beach, Ubatuba, State of São Paulo, Brazil. Black squares indicate a deviation from a 1:1 sex ratio.
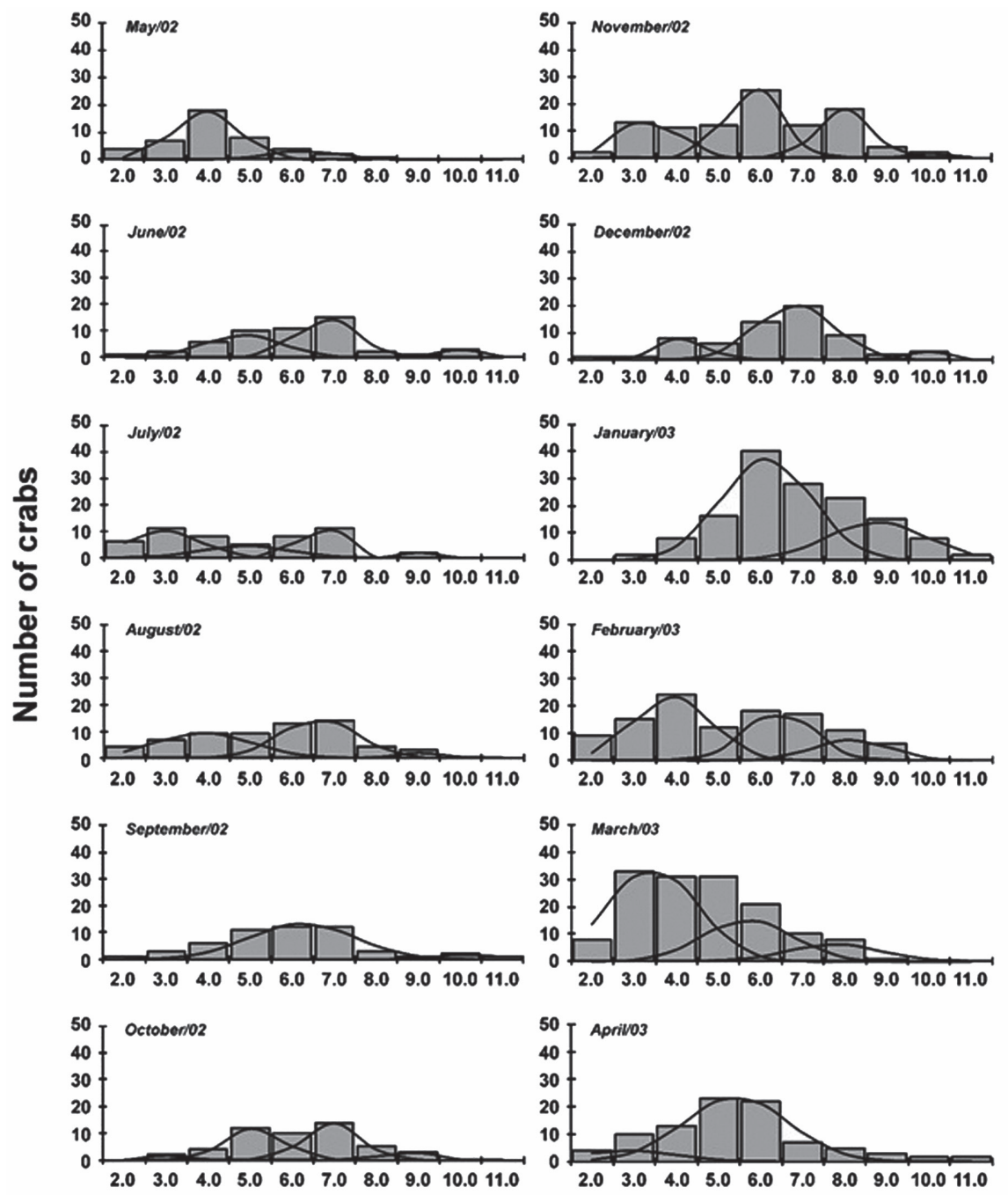

Carapace width class $(\mathrm{mm})$

Figure 6. Monthly size frequency distribution of Panopeus austrobesus, indicating the modal curve evaluation, in the mussel farm at Itaguá Beach, Ubatuba, State of São Paulo, Brazil. 

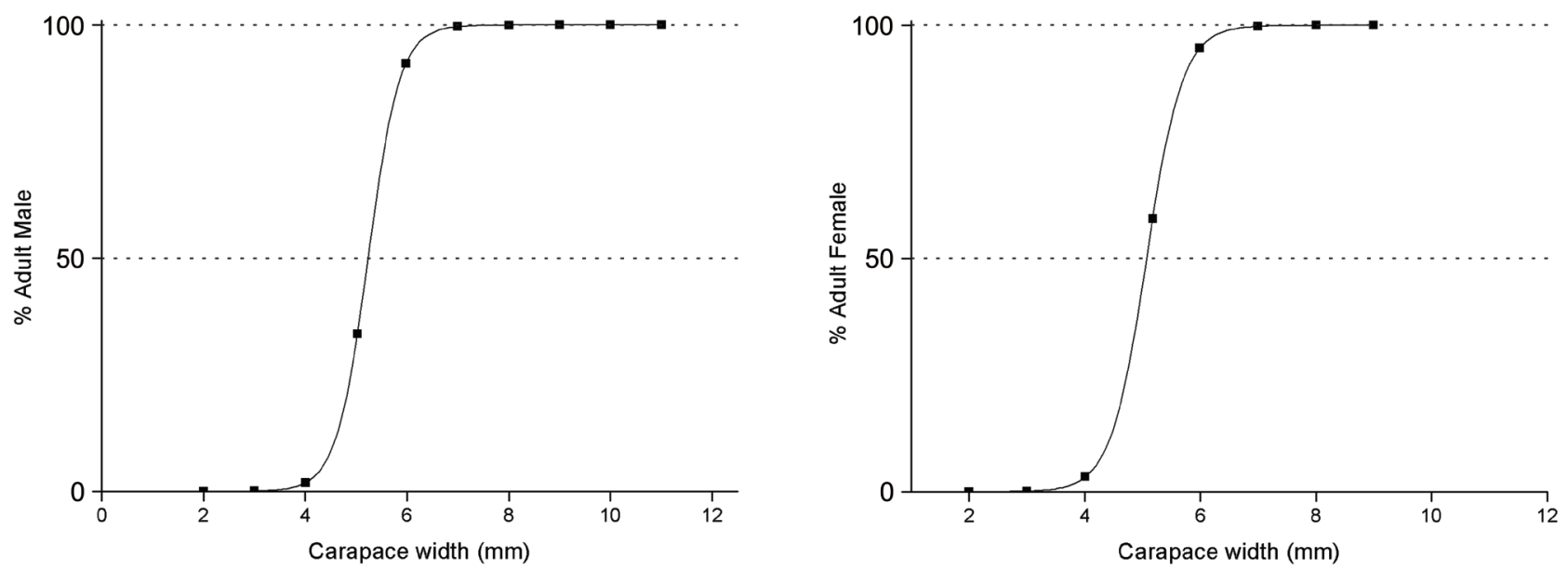

Figure 7. Adjustment of the logistic function, indicating carapace width (CW) of Panopeus austrobesus, where 50\% of the crabs are morphologically mature, in the mussel farm at Itaguá Beach, Ubatuba, State of São Paulo, Brazil.

$\pm 2.66^{\circ} \mathrm{C}$ ), with the lowest value recorded in August 2002 and the highest in February 2003. Salinity ranged from 30.3 to $35.5(33.3 \pm 1.68)$, with the lowest salinity in October 2002 and the highest in June 2003. The recorded temperature and salinity values suggest the predominance of coastal water in the study area, as pointed out in the T-S diagram (Fig. 8). In addition, the salinity and bottom water temperature were negatively associated with the absolute abundance of $P$. austrobesus (Spearman test, $\mathrm{p}>0.05$ ).

\section{Discussion}

The panopeid $P$. austrobesus is reported as exploiting a large environmental range, from estuarine zones to exclusively marine habitats (Melo, 1996), which suggests a broad ecological valence. This wide ecological distribution may be responsible for the large sizes recorded in the mussel farms in marine environments, as observed in this study $(5.7 \pm 1.5$ and $5.4 \pm 2.2$ $\mathrm{mm} \mathrm{CW}$ for males and females, respectively), when compared with the specimens sampled in estuarine zones $(16.1 \pm 8.8$ and $13.3 \pm 6.7 \mathrm{~mm} \mathrm{CW}$ for males and females, respectively), reported by Negreiros-Fransozo and Fransozo (2003). Differences in the mean sizes within the same species from different areas have been recorded for other species, especially for those that inhabit both marine and estuarine environments, such as Aratus pisonii (H. Milne Edwards, 1837) (Conde and Díaz, 1989). According to these authors, differences in salinity can be responsible for restricting crab growth, mainly due to the control of osmoregulation.

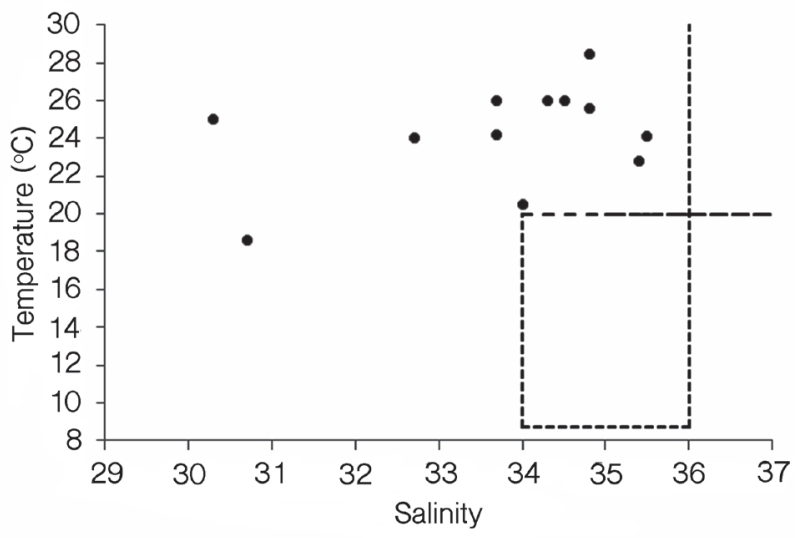

Figure 8. T-S diagram indicating the presence of water masses in the study region from May 2002 to April 2003.

The difference in sizes recorded in this study, when compared with those reported by Negreiros-Fransozo and Fransozo (2003), seem to corroborate the results of Conde and Díaz (1992), which demonstrated that crabs in estuarine and riverine environments reach larger sizes when compared to crabs in hypersaline and marine habitats. Alves et al. (2012a; 2012b) also recorded a similar mean size for specimens of $P$. austrobesus from the Vitoria Archipelago (mean size = $5.4 \pm 1.5 \mathrm{~mm} \mathrm{CW}$ ) and Itaguá Beach (mean size $=6.9$ $\pm 4.6 \mathrm{~mm} \mathrm{CW})$, both of which are on the northeastern coast of São Paulo state, Brazil. It is probable that the negative association between the absolute abundance of P. austrobesus in the conditions of salinity and bottomwater temperature recorded in this investigation can be explained by the same reasons.

The recorded differences in the mean size and abundance of $P$. austrobesus populations from marine 
and estuarine habitats can be related to the following hypotheses: first, the marine population studied here is composed of juveniles and individuals that have just reached the adult phase, which recently initiated the colonization, since the nets were installed exclusively for this study. However, this hypothesis can be refuted, as the same mean sizes were reported by Alves et al. (2012a; 2012b) for marine habitats. Second, the restricted size can also be an adaptation for exploiting the microhabitats in the farming nets. Alves et al. (2012a; 2012b) may corroborate this hypothesis, as the nets obtained crabs from rock crevices, which also offer small-sized refuges. Third, estuarine areas had a larger productivity than marine areas. Food availability can contribute to size determination of the $P$. austrobesus mussel culture, and the large differences in the food items available in the estuarine and marine environments must be accounted for. Additional studies that focus on this subject are needed in order to obtain more precise information concerning size restriction, verified to $P$. austrobesus individuals in mussel farms.

In spite of the individual size differences, the population structure of $P$. austrobesus in the mussel farm reveals the same general trends verified for the estuarine population, previously reported as unimodal and non-normal distribution (Negreiros-Fransozo and Fransozo, 2003), which was skewed towards the left and showed larger males than females. These features seem to be adaptive trends with regard to boundary environmental conditions, such as the high salinity of the marine environments or the significant salinity variability in the estuaries. This pattern in the frequency distribution is common for tropical decapod populations and may suggest a stable population with constant recruitment and mortality rates (Conde and Díaz, 1989).

The mean size of the population sampled in the mussel farm was lower than that reported by Negreiros-Fransozo and Fransozo (2003), which must be explained as a result of the population being newly settled, taking into account that the mussel nets were installed exclusively for this investigation. It is also possible that the population still did not reach its final size. Males of $P$. austrobesus reached larger sizes than females, and these characteristics must be associated with differences in energy budgets. Females must have reduced somatic growth when compared to males, because their energetic budget drives gonad development (Mantelatto and Fransozo, 1996; LópezGreco et al., 2000). On the other hand, males may reach larger sizes to succeed in intra-specific competition, which is part of a strategy to maximize reproductive success and to gain a selective advantage in accessing mating partners (Abrams, 1988; Gherardi et al., 1989).

According to Wenner (1972), a deviation from the $1: 1$ ratio is expected for adult marine crustaceans, as is here verified for $P$. austrobesus with a male-biased sex ratio over the sample period. This result matches the anomalous pattern observed by Wenner (1972), in which one sex is concentrated in the intermediary size classes and the other one dominates the low- and highend size classes, providing evidence for the differential growth of males and females. For P. austrobesus, as for brachyuran crabs in general, this differential growth rate is strongly related to reproduction tasks. Females allocate most of their energy to reproduction, especially during the incubation season, when somatic growth events cease, resulting in restricted female growth when compared to males (Adiyody and Adiyody, 1970; Wenner, 1972).

Recruitment of $P$. austrobesus seems to be constant in the mussel farm. The crab frequency of the first size class over the entire sampling period was constant, suggesting a constant larval supply. Continuous recruitment is expected for tropical and subtropical decapod populations once the reproduction patterns of these animals are continuous, which would thus create a constant larval supply (Giese, 1959; Erdman and Blake, 1987; Negreiros-Fransozo et al., 1992). According to Queiroga et al. (1994), there is evidence that many crustacean species, including estuarine species, maintain their migration processes during larval development. This exposes the larvae to other marine environments as they develop, before they return to the parental environment and settle into the original population. In this process, the mussel farms act like "islands" for settlement, offering the hard substrata needed by the crab to establish during the zoeal phase.

González-Gurriarán et al. (1982) point out that an abundance of resources, such as food and space, in a given environment must result in the exponential increase of the reproductive output and, subsequently, of juvenile recruitment. Similarly, both food and space 
are available for crabs in the mussel farm nets, thus constituting a suitable site for population development, as seems to occur for $P$. austrobesus verified in this investigation.

During most of the study period, the mussel farm was under the influence of the coastal water (CW) mass $\left(\mathrm{T}>20^{\circ} \mathrm{C}, \mathrm{S}<36\right)$, which is typical for most of the Brazilian coast. Therefore, this coastal water mass is probably the main environmental parameter that constrains the development of crab populations in this region, contributing to the stability of the main regulating factors of the population, such as reproduction and recruitment. The role played by variations of temperature and salinity has previously been reported as a proximal feature of the spatial distribution and dynamic population modeling for crustaceans, including the brachyuran crabs (De Léo and Pires-Vanin, 2006). In this way, the low variation within these environmental parameters must be equally responsible for the general population structure assigned for $P$. austrobesus in this investigation.

As submerged algae beds, mussel rafts allow for the maintenance of benthic species on the water column, accessing this new habitat by larval dispersion (Hovel, 2003). According to Flores and Paula (2002), while the life history characteristics of the evolution of the species change over time, the establishment and permanency of a population in a given habitat are conditioned to intermittent and even fortuitous events that guarantee the supply of new recruits. In this sense, the emergence of a new hard substratum in the pelagic zone seems to be an oasis for the establishment of larvae. It may also provide food and protection as a function of the mussel rafts.

However, even the mussel farms, being new structures on the sea, have the potential to modify the environment. Mussels are producers of biodeposits, and organic matter and shell debris accumulate in the pelagic zone and on the benthic floor, generating pollution that may affect the environment and the biota in the area. This can modify the natural balance among species, inverting the dominance patterns and even contributing to the entrance of tolerant species into the community (Schetinni et al., 1996; Chamberlain et al., 2001; Mirto et al., 2000).

In general, mussel farms represent an anthropogenic intervention in the seascape, causing some environmental changes that may affect the natural dynamics. However, these structures must allow for the introduction of many species, increasing their ecological and even geographical distribution, which will expand the amount of available space and food to establish new populations. This is particularly important for some of those small populations such as $P$. austrobesus, which exhibit almost the same general trends as those verified for the estuarine population (Negreiros-Fransozo and Fransozo, 2003).

The $P$. austrobesus sampled here may attest the environmental counterpart role of the mussel farms since they can support populations. It may also help to reintroduce them into this area, where they can then be used to generate economic profits. They may also act as a bioremediation tool, guaranteeing the maintenance of the genetic patrimony in the region.

\section{ACKNOWLEDGEMENTS}

The authors are indebted to Alexandre Novaes for providing the logistical facilities concerning the sea farm use. All sampling in this study was conducted in accordance with applicable state and federal laws. The authors also thank the Universidade de Taubaté for supporting this study by grants to V.J. Cobo (\#251/2001-PRPPG).

\section{References}

Abrams, P.A. 1988. Sexual difference in resource use in hermit crabs: consequences and causes. p. 283-296. In: G. Chelazzi and M. Vanninni (eds), Behavioral Adaptations to Intertidal Life. New York, Plenum.

Adiyody, K.G. and Adiyody, R.G. 1970. Endocrine control of reproduction in decapod crustacean. Biological Reviews, 45 : 121-165.

Aguillar, A.T.; Malpica, Z.C. and Urbina, B.V. 1995. Dinamica de poblaciones de peces. Peru, Concytec, 304p.

Antoniadou, C.; Voultsiadou, E.; Rayann, A. and Chintiroglou, C. 2013. Sessile biota fouling farmed mussels: diversity, spatiotemporal patterns, and implications for the basibiont. Journal of the Marine Biological Association of the United Kingdom, 93: 1593-1607.

Alves D.F.R.; Barros-Alves, S.P.; Cobo, V.J.; Lima, D.J.M. and Fransozo, A. 2012a. Checklist of the brachyuran crabs (Crustacea, Decapoda) in the rocky subtidal of Vitória Archipelago, southeast coast of Brazil. Check List, 8: 940-950.

Alves, D.F.R.; Carvalho, M.C.R.; Barros-Alves, S.P. and Cobo, V.J. 2012b. Brachyuran crabs (Decapoda, Brachyura) associated with the green sponge Amphimedon viridis (Demospongiae) from Itaguá beach, south-eastern coast of Brazil. Crustaceana, 85: 497-512. 
Boscardin, N.R. 2007. A produção aquícola brasileira. In: A. Ostrenski; J.R. Borghetti and D. Soto (eds), Estudo Setorial para consolidação de uma aquicultura sustentável no Brasil. Curitiba, GIA, p. 44-95.

Castro-Filho, B.M. and Miranda, L.B.D. 1998. Physical oceanography of the western Atlantic continental shelf located between $4^{\circ} \mathrm{N}$ and $34^{\circ} \mathrm{S}$ coastal segment (4,W). p. 209-251. In: A.R. Robinson and K.H. Brink (eds.), The Sea. New York, John Wiley and Sons.

Castro-Filho, B.M.; Miranda, L.B. and Myao, S.Y. 1987. Condições hidrológicas na plataforma continental ao largo de Ubatuba: Variações sazonais e em média escala. Boletim do Instituto Oceanográfico, 35: 135-151.

Chamberlain, G.; Avnimelech, Y.; McIntosh, R.P. and Velasco, M. 2001. Advantages of aerated microbial reuse systems with balanced C: N, II. Composition and nutritional value of organic detritus. Global Aquaculture Advocate, June: 22-24.

Cinar, M.E.; Katagan, T.; Kocak, F.; Ozturk, B.; Ergen, Z.; Kocatas, A.; Onen, M.; Kirkim, F.; Bakir, K.; Kurt, G.; Dagli, E.; Acik, S.; Dogan, A. and Ozcan, T. 2008. Faunal assemblage of the mussel Mytilus galloprovincialis in and around Alsancak Harbour (Izmir Bay, eastern Mediterranean) with special emphasis on alien species. Journal of Marine Systems, 71: 1-17.

Conde, J.E. and Díaz, H. 1989. The mangrove tree crab Aratus pisonii in a tropical estuarine coastal lagoon. Estuarine Coastal and Shelf Science, 28: 639-650.

Conde, J.E. and Díaz, H. 1992. Variations in intraspecific relative size at the onset of maturity (RSOM) in Aratus pisonii ( $\mathrm{H}$. Milne-Edwards, 1837) (Decapoda, Brachyura, Grapsidae). Crustaceana, 62: 214-216.

De Léo, F.C. and Pires-Vanin, A.M.S. 2006. Benthic megafauna communities under the influence of the South Atlantic Central Water intrusion onto the Brazilian SE shelf: a comparison between an upwelling and a non-upwelling ecosystem. Journal of Marine Systems, 60: 268-284.

Erdman, R.B. and Blake, N.J. 1987. Population dynamics of the sponge-dwelling alpheid Synalpheus longicarpus, with observations on S. brooksi and S. pectiniger, in shallowwater assemblages of the eastern Gulf of Mexico. Journal of Crustacean Biology, 7: 328-337.

Flores, A.A.V. and Paula, J. 2002. Sexual Maturity, larval release and reproductive output of two Brachyuran crabs from a rock intertidal area in central Portugal. Invertebrate Reproduction and Development, $42: 21-34$.

FAO. Fishstat Plus: universal software for fishery statistical time series. Version 2.3, 2012.

Fraga, F. 1981. Upwelling off the glacial coast. Northwest Spain. p. 176-182. In: F.A. Richards (ed), Coastal Upwelling. 1. Washington D.C., American Geophysical Union.

Gherardi, F.; Tarducci, F. and Micheli, F. 1989. Energy maximization and foraging strategies in Potamon fluviatile (Decapoda, Brachyura). Freshwater Biology, 22: 233-245.

Gibbs, M.; Funnell, G.A.; Pickmere, S.; Norkko, A. and Hewitt, J. 2005. Benthic nutrient fluxes along an estuarine gradient of the pinnid bivalve Atrina zelandica in summer. Marine Ecology Progress Series, 288: 151-164.

Giese, A.C. 1959. Comparative physiology: Annual reproductive cycles of marine invertebrates. Animal Review of Physiology, 21: 547-576.
González-Gurriarán, E.; Freire, J. and Fernádez, L. 1982. Influence of mussel raft on spatial and seasonal abundance of crabs in the Ria de Arousa, North-West, Spain. Marine Biology, 72: 201-210.

Gutierrez, J.L.; Jones, C.G.; Strayer, D.L. and Iribarne, O.O. 2003. Mollusks as ecosystem engineers: the role of shell production in aquatic habitats. Oikos, 101: 79-90.

Herbert, R.A. 1999. Nitrogen cycling in coastal marine ecosystems. FEMS Microbiology Reviews, 23: 563-590.

Hovel, K.A. 2003. Habitat fragmentation in marine landscapes: relative effects of habitat cover and configuration on juvenile crab survival in California and North Carolina seagrass beds. Biological Conservation, 110: 401-12.

Keunecke, K.A.; Vianna, M.; Fonseca, D.B.F. and D’ Incao, F. 2007. The pink-shrimp trawling bycatch in the northern coast of São Paulo, Brazil, with emphasis on crustaceans. Nauplius, 15: 49-55.

Kemp, W. M. and Boynton, W.R. 1984. Spatial and temporal coupling of nutrient inputs to estuarine primary production: The role of particulate transport and deposition. Bulletin of Marine Science, 35: 522-535.

López-Greco, L.S.; Hernandez, J.E.; Bolaños, J.; Rodrígues, E.M. and Hernandéz, G. 2000. Population features of Microphrys bicornutus Latreille, 1825 (Brachyura, Majidae) from Isla Margarita, Venezuela. Hydrobiologia, 439: 151-159.

Macedo, P.P.B.; Masunari, S. and Corbetta, R. 2012. Crustáceos decápodos associados às cordas de cultivo do mexilhão Perna perna (Linnaeus, 1758) (Mollusca, Mytilidae) na Enseada da Armação do Itapocoroy, Penha - SC. Biota Neotropica, 12: $185-195$.

Mahiques, M.M.; Tessler, M.G.; Ciotti, A.M.; Silveira, I.C.A.; Souza, S.H.M.; Figueira, R.C.L.; Tassinari, C.C.G.; Furtado, V.V. and Passos, R.F. 2004. Hydrodynamically driven patterns of recent sedimentation in the shelf and upper slope off Southeast Brazil. Continental Shelf Resarch, 24: 1685-1697.

Mantelatto, F.L.M. and Fransozo, A. 1996. Size at sexual maturity in Callinectes ornatus (Brachyura, Portunidae) from the Ubatuba region (SP), Brazil. Nauplius, 4: 29-38.

Marochi, M.Z. and Masunari, S. 2011. Os caranguejos Eriphiidae, Menippidae, Panopeidae e Pilluminidae (Crustacea, Brachyura) de águas rasas do litoral do Paraná, com chave pictórica de identificação para as espécies. Biota Neotropica, 11:21-33.

Melo, G.A.S. 1996. Manual de identificação dos Brachyura (caranguejos e siris) do litoral brasileiro. São Paulo, Editora Plêiade, 604p.

Mirto, S.; La Rosa, T.; Danovaro, R. and Mazzola, A. 2000. Microbial and meiofaunal response to intensive musselfarm biodeposition in coastal sediments of the western Mediterranean. Marine Pollution Bulletin, 40: 244-252.

Montú, M.; Anger, K.; Bakker, C. de; Anger, V. and LoureiroFernandes, L. 1988. Larval development of the Brazilian mud crab Panopeus austrobesus Williams, 1983 (Decapoda, Xanthidae), reared in the laboratory. Journal of Crustacean Biology, 8: 594-613.

Negreiros-Fransozo, M.L. and Fransozo, V. 2003. A morphometric study of the mud crab, Panopeus austrobesus Willians, 1983 (Decapoda, Brachyura) from a subtropical mangrove in South America. Crustaceana, 76: 281-294. 
Negreiros-Fransozo, M.L.; Reigada, A.L.D. and Fransozo, A. 1992. Braquiúros (Crustacea, Decapoda) dos sedimentos sublitorais da praia da enseada, Ubatuba (SP). Boletim do Instituto de Pesca, 19: 17-22.

Ng, P.K.L.; Guinot, D. and Davie, P.J.F. 2008. Systema brachyurorum: Part I. An annoted checklist of extant brachyuran crabs of the world. Raffles Bulletin of Zoology, Suppl. 17: 1-218.

Peluffo, E. 2004. Panopeus austrobesus, 1983 (Decapoda Brachyura), a first record of the Brazilian mud crab at Uruguayan Atlantic Coast. Nauplius, 12: 57-58.

Pimenta, A.M.; Barutot, R.A.; D’Incao, F. and Fonseca, D.B. 2005. Growth of Armases rubripes (Rathbun, 1987) in the estuary of the lagoa dos Patos, Southern Brazil. Nauplius, 13: 183-189.

Queiroga, H.; Costlow, J.D. and Moreira, M.H. 1994. Larval abundance patterns of Carcinus maenas (Decapoda, Brachyura) in Canal de Mira (Ria de Aveiro, Portugal). Marine Ecology Progress Series, 111: 63-72.

Rocha, J.M.; Milliman, J.D.; Santana, C.I. and Vicalvi, M.A. 1975. Southern Brazil. p. 117-150. In: J.D. Milliman and C.P. Summerhayes (eds), Contributions to Sedimentology, 4. Upper continental margin sedimentation off Brazil. Stuttgart, Schweizerbart Science Publishers.
Schettini C.A.F.; Carvalho, J.L.B. and Jabor, P. 1996. Comparative hydrology and suspended matter distribution of four estuaries in Santa Catarina State - Southern Brazil. p. 29-32. In: Workshop on Comparative Studies of Temperate Coast Estuaries. Proceedings, IADO.

Thiel, M. and Ullrich, N. 2002. Hard rock versus soft bottom: the fauna associated with intertidal mussel beds on hard bottoms along the coast of Chile, and considerations on the functional role of mussel beds. Helgoland Marine Research, 56: 21-30.

Vazzoler, A.E.A.M. 1996. Biologia da reprodução de peixes teleósteos: teoria e prática. Maringá, Eduem, 169p.

Vieira, R.R.R. and Calazans, D.K. 2010. Chave ilustrada para identificação das zoés de Brachyura do estuário da Lagoa dos Patos (RS) e região costeira adjacente. Biota Neotropica, 10: 431-437.

Wenner, A.M. 1972. Sex ratio as a function of size in marine Crustacea. American Naturalist, 106: 321-350.

Wooster, W.S.; Bakun, A. and McLain, D.R. 1976. The seasonal upwelling cycle along the eastern boundary of the North Atlantic. Journal of Marine Research, 34: 131-141.

Wilson, K. and Hardy, I.C.W. 2002. Statistical analysis of sex ratios: an introduction. p. 48-92. In: Sex Ratios. Concepts and Research Methods. Cambridge, Cambridge University Press. 